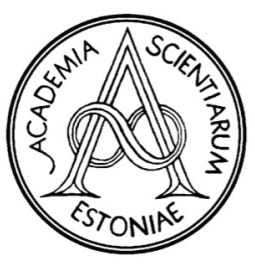

Proceedings of the Estonian Academy of Sciences, $2021,70,2,148-154$

https://doi.org/10.3176/proc.2021.2.05

Available online at www.eap.ee/proceedings

\title{
UWB monopole patch antenna with two H-shaped slots and dual-band notch for WLAN and WiMAX applications
}

\author{
Furat Abayaje $^{\mathrm{a}}$, Yaqeen Sabah Mezaal ${ }^{\mathrm{b} *}$ and Ban M. Alameric
}

\author{
${ }^{a}$ Department of Software Engineering, University of Mosul, Iraq \\ ${ }^{\mathrm{b}}$ Medical Instrumentation Engineering Department, Al-Esraa University College, Baghdad, Iraq \\ ${ }^{\mathrm{c}}$ Department of Electrical Engineering, Faculty of Engineering, Mustansiriyah University, Baghdad, Iraq
}

Received 2 August 2020, accepted 8 February 2021, available online 13 April 2021

(C) 2021 Authors. This is an Open Access article distributed under the terms and conditions of the Creative Commons AttributionNonCommercial 4.0 International License (http://creativecommons.org/licenses/by-nc/4.0/).

\begin{abstract}
Ultra Wide Band (UWB) denotes a wireless technology developed to transfer data at high rates over very short distances and at low power densities. In this paper, a highly miniaturized monopole antenna with a dual-notch band is presented for Wireless Local Area Network (WLAN) and Worldwide Interoperability for Microwave Access (WiMAX) systems. The overall size of the broadband antenna was reduced to $22 \mathrm{~mm}^{2} \times 20 \mathrm{~mm}^{2}$, which improved the UWB operation in the frequency range $(2.4 \mathrm{GHz}-9.6 \mathrm{GHz})$. Etching two H-shaped slots on the radiating patch of the antenna was implemented to reject the WiMAX frequency range from 3.1 $\mathrm{GHz}$ to $3.9 \mathrm{GHz}$ and the WLAN frequency range from $5.1 \mathrm{GHz}$ to $5.9 \mathrm{GHz}$. Thus, the monopole patch antenna has dual H-shaped slots etched on the radiating patch. The antenna was printed on FR4 dielectric substrate and fed by a coplanar waveguide (CPW). The coaxial feed was used to obtain an impedance matching of $50 \Omega$. The antenna exhibits omnidirectional and bi-directional radiation performance in the H- and E-planes, respectively. In addition, it was tested and verified in practice.
\end{abstract}

Key words: UWB, monopole antenna, H-shaped slots, dual-band notch.

\section{INTRODUCTION}

UWB wireless communication has spread worldwide as the Federal Communications Commission (FCC) approved the unauthorized frequency band ranging from $3.1 \mathrm{GHz}$ to $10.6 \mathrm{GHz}$ in 2002. Microwave engineers are increasingly requesting the UWB antenna with a small size, low profile, good impedance matching, group delay, and two radiation patterns (bi-directional and omnidirectional patterns) [1-3].

Many studies have been performed to design smallsized multiband antennas that can tolerate various communication applications (WLAN/5.15GHz-5.35GHz band) and technologies (WiMAX/3.3GHz-3.7GHz band). Therefore, to avoid interference with other bands, a filter antenna must be designed to reject the unwanted bands. The single

\footnotetext{
*Corresponding author, yaqeen@esraa.edu.iq
}

or dual etching of U-, H-, C-, W-shaped slots and elliptical slots on the radiation patches or the ground plane of an antenna is a way to realize notched-band features [4-6].

The stopping frequency of the band is feasibly satisfied by adjusting the length, width, and radius of these structures. The advantage of designing a multiband antenna is to provide multiple frequency bands in a single antenna, reducing manufacturing costs as well as complex design and operation [6-9]. There are many methods for obtaining a band-notch function in a UWB antenna that is integrated with the ground plane or radiation patch by using Split Ring Resonator (SRR) [10], Tapered Slot Edge (TSE) [11], Electromagnetic Band-Gap (EBG) [12], Complementary Split-Ring Resonator (CSRR) and Defective Ground Structure (DGS) [13].

The application of fractal geometry can be adopted to achieve miniaturization and broadband frequency re- 
sponse because of its space-filling and multi-resonance characteristics [14-17]. Accordingly, the UWB antennas with notched bands based on fractals are reported, such as circular fractal [18], Koch fractal [19], and rectangle tree fractal [20].

In this study, new H-shaped slots etched on the monopole radiation patch antenna were employed for UWB with WiMAX and WLAN dual-band rejections. Furthermore, by cutting one square notch in the ground plane, we can produce wide impedance bandwidth at the higher band. The proposed antenna design provides UWB response with a dual-band notch without increasing the size of the antenna, in addition to the benefits of its simple topology, small dimensions, low profile, and acceptable gain features.

The main objective of this research was to transmit and receive line codes without the requirement of analog modulations by wireless baseband transmission technique, like in Manchester and Polar Return-to-Zero encodings [3]. The operation of the antenna was investigated by HFSS v. 15.0 simulator using FR4 substrate. The design and dimension details of the proposed multiband antenna are discussed and provided in Section 2. In Section 3, the effect of different slot parameters on the antenna frequency response is investigated besides the simulation results of surface current, radiation patterns, voltage standing wave ratio, and gain. Moreover, experimental results are presented and compared to the simulated ones. Section 4 presents the concluded and highlighted points of this study.

\section{ANTENNA DESIGN}

The layout details of the designed monopole patch antenna fed by the CPW and simulated by the HFSS electromagnetic simulator are provided in Fig.1. In this paper, we introduce the UWB antenna based on the power divider and slot ground plane with dual H-shaped slots etched on the patch radiator. The monopole antenna is based on the FR4 substrate with a thickness of $1.6 \mathrm{~mm}$, a dielectric constant of 4.4, and a loss tangent of 0.02 . The feed line has a characteristic impedance of $50 \Omega$, and the full dimensions of the proposed antenna are $22 \mathrm{~mm}^{3} \times 20 \mathrm{~mm}^{3}$ $\times 1.6 \mathrm{~mm}^{3}$. The designed impedance bandwidth range with $\mathrm{S} 11 \leq-10 \mathrm{~dB}$ is $2.4-9.6 \mathrm{GHz}$. The antenna's width and length along with the dimensions of H-shaped slots were calculated using the following equations [21]:

$$
\begin{aligned}
W & =\frac{C}{2 f_{r}} \sqrt{\frac{2}{\varepsilon_{r}+1}}, \\
L & =\frac{C}{2 f_{r} \sqrt{\varepsilon_{\text {reff }}}}-2 \Delta L, \\
L_{\text {slot }} & =\frac{C}{2 f_{r} \sqrt{\varepsilon_{\text {reff }}}},
\end{aligned}
$$

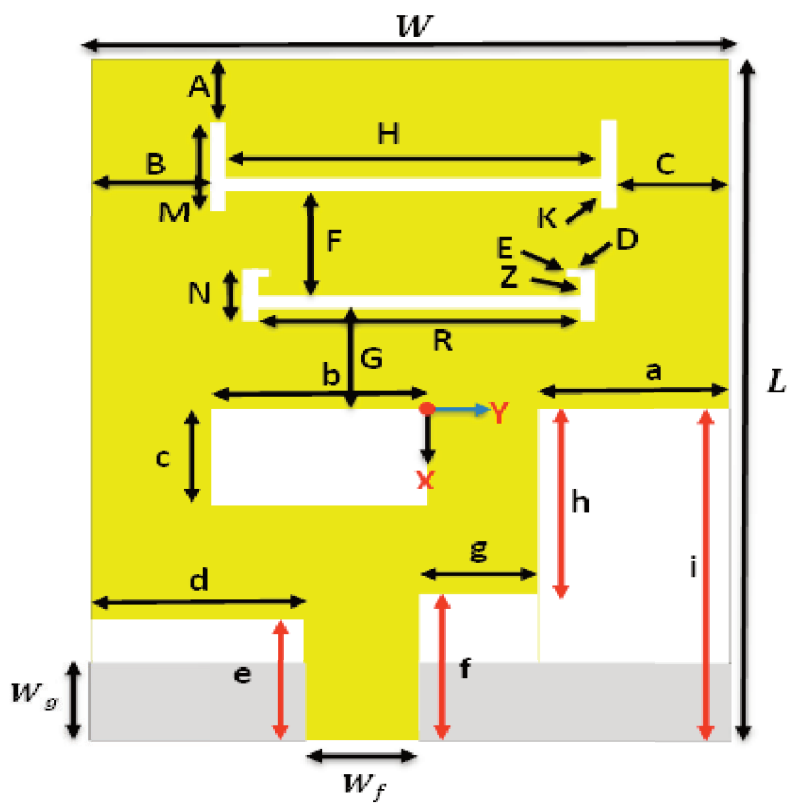

Fig. 1. Dimensions of the monopole antenna (in $\mathrm{mm}$ ).

where $C$ represents the speed of light $(0.3 \mathrm{Gm} / \mathrm{s}), f_{r}$ is the resonance frequency at $6 \mathrm{GHz}, \varepsilon_{r}$ is the dielectric constant of FR4 material, and $\varepsilon_{\text {reff }}$ denotes the effective dielectric constant for the same material that was determined by the HFSS simulator.

$\mathrm{L}=22, \mathrm{~W}=20, W_{f}=3.4, W_{g}=2.5, \mathrm{a}=6.6, \mathrm{~b}=6.3, \mathrm{c}=3.6$, $\mathrm{d}=6.6, \mathrm{e}=3.94, \mathrm{f}=4.2, \mathrm{~g}=3.4, \mathrm{~h}=6.8, \mathrm{I}=11, \mathrm{~A}=1$, $\mathrm{B}=\mathrm{C}=2.5, \mathrm{D}=0.7, \mathrm{E}=0.2, \mathrm{~F}=\mathrm{G}=1.5, \mathrm{H}=14, \mathrm{~K}=\mathrm{Z}=0.5$, $\mathrm{R}=12.4, \mathrm{M}=6, \mathrm{~N}=2$.

\section{RESULTS AND DISCUSSION}

As a starting point, an initial topology of the monopole antenna was simulated to investigate the UWB performance on a bandwidth ranging from $2.4 \mathrm{GHz}$ to $9.6 \mathrm{GHz}$. The range of UWB was provided by using a modified rectangle slot on the patch radiator and the ground plane.

The lower operating frequency was observed by cutting a rectangle in the radiating patch and the ground plane. The higher operating frequency was observed through the stripline feed, as shown in Fig. 2. This figure is based on the reference antenna without H-shaped slots. Several narrow bands for other wireless systems, like WLAN and WiMAX, may cause interference with the UWB application. For that reason, the band notching method is practicably used to minimize potential interferences.

\subsection{H-shaped slot on the patch radiator}

In this section, one H-shaped slot was first etched on the top of the radiation patch, which can notch the 


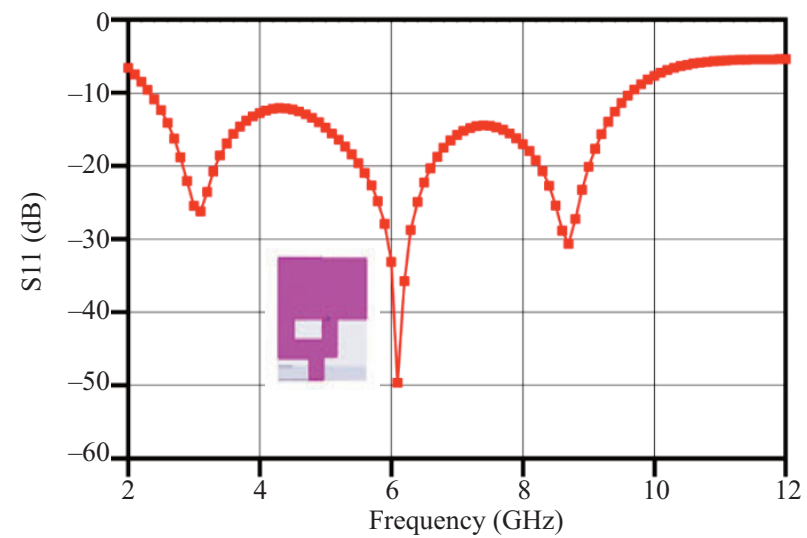

Fig. 2. Simulated S11 for the reference antenna with the bandwidth ranging from $2.4 \mathrm{GHz}$ to $9.6 \mathrm{GHz}$.

WiMAX frequency band at $3.35-3.83 \mathrm{GHz}$, as depicted in Fig. 3.

Figure 3 illustrates the simulated S11 response for the antenna with an $\mathrm{H}$-shaped slot in the radiating patch. It has the identical basic topology of the original antenna to provide an operating frequency range of $2.4-9.6 \mathrm{GHz}$ with a band-notched range from $3.35 \mathrm{GHz}$ to $3.83 \mathrm{GHz}$ for WiMAX behaviour. The slot length was determined by means of Eq. 3 after assuming that the rejected band was centered at $3.7 \mathrm{GHz}$. The calculated length of the slot is equal to $24.45 \mathrm{~mm}$. In contrast, the optimized length of the slot is equal to $25 \mathrm{~mm}$, where the difference between the calculated and optimized values is about $2.25 \%$ based on trial and error criteria.

In the next step, the second H-shaped slot was embedded on the centered radiation patch to investigate its S11 response, as depicted in Fig. 4. The simulated S11 response of the antenna with a slot reveals the UWB behaviour with a bandwidth range from $2.4 \mathrm{GHz}$ to $9.6 \mathrm{GHz}$, and the rejected band was centered at $5.7 \mathrm{GHz}$ with a band-notched range from $4 \mathrm{GHz}$ to $6 \mathrm{GHz}$ for

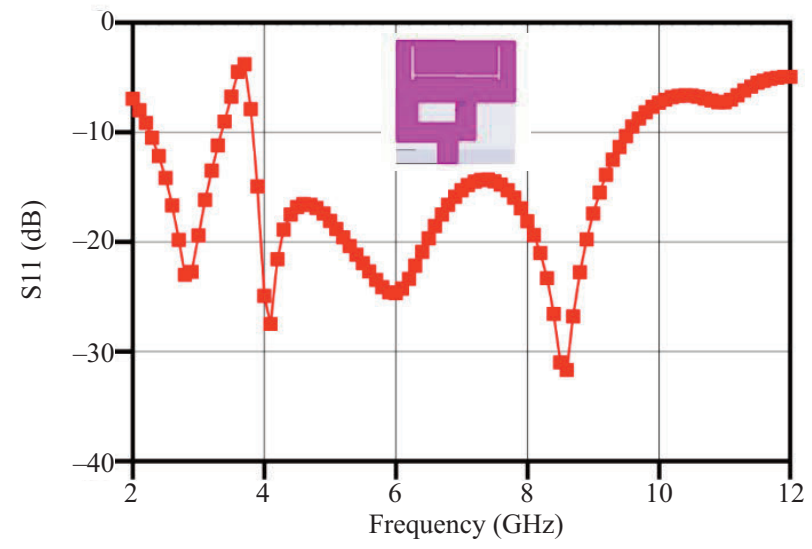

Fig. 3. Simulated S11 response with one H-shaped slot printed on the top of the radiating patch.

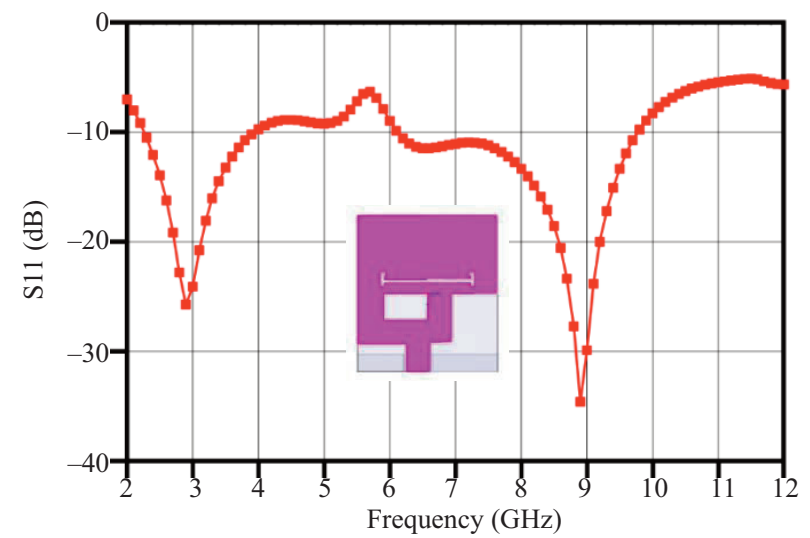

Fig. 4. Simulated S11 response with one H-shaped slot etched on the top of the radiating patch.

WLAN behaviour. The calculated length of the slot is equal to $15.87 \mathrm{~mm}$ by Eq. 3, and the optimized length is equal to $16.8 \mathrm{~mm}$, where the difference between them is about $5.54 \%$.

In the last step, the antenna with two H-shaped slots was printed on the radiating patch, and its S11 response is illustrated in Fig. 5. After introducing the two slots into the radiating patch of the antenna, the simulation outcome reveals that the antenna is still operated within the frequency band from $2.4 \mathrm{GHz}$ to $9.6 \mathrm{GHz}$. At the same time, two extra resonances were presented to the passband of the antenna. One of these resonances is responsible for introducing the WiMAX band, and the other presents the WLAN band, as shown in Fig. 5. It was detected that by inserting dual $\mathrm{H}$-shaped slots on the radiating patch, the two rejected bands are effectively improved under WiMAX and WLAN frequency ranges.

Table 1 describes the comparison between the suggested antenna and other reported antennas in $[4,5,10$, 13,22-24] in terms of size, employed substrate type, design principle, available WiMAX notch range, available

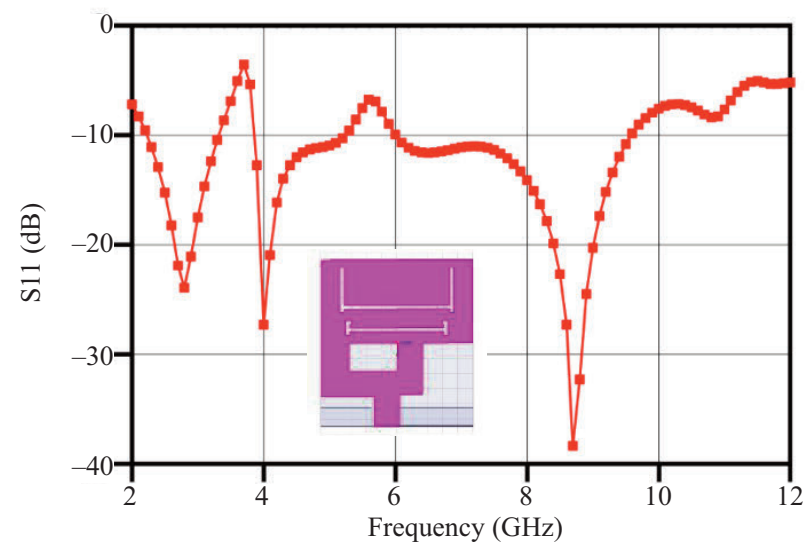

Fig. 5. Simulated S11 response with two H-shaped slots etched on the proposed antenna's radiating patch. 
Table 1. Comparison between the suggested antenna and other reported antennas in $[4,5,10,13,22-24]$

\begin{tabular}{|c|c|c|c|c|c|c|}
\hline Ref. & Dimensions $\left(\mathrm{mm}^{3}\right)$ & $\begin{array}{c}\text { Substrate } \\
\text { type }\end{array}$ & Design principle & $\begin{array}{l}\text { WiMAX notch } \\
\text { range }(\mathrm{GHz})\end{array}$ & $\begin{array}{l}\text { WLAN notch range } \\
(\mathrm{GHz})\end{array}$ & $\begin{array}{l}\text { No. of notched } \\
\text { bands }\end{array}$ \\
\hline [4] & $46 \times 42 \times 1$ & FR-4 & $\begin{array}{l}\text { U-slot in the ground structure } \\
\text { and U-shaped slot in the } \\
\text { radiating patch }\end{array}$ & $3.3-4$ & $5-6$ & 2 \\
\hline [5] & $30 \times 30 \times 1.524$ & RO4350B & $\begin{array}{l}\mathrm{C} \text {-slots in the radiating patch } \\
\text { and reduced ground plane }\end{array}$ & $3.2-3.85$ & $5.1-5.9$ & $\stackrel{3}{\text { (including C-band) }}$ \\
\hline [10] & $35 \times 30 \times 1.59$ & FR-4 & $\begin{array}{l}\text { C-shaped circular slot and } \\
\text { SRR }\end{array}$ & $3.2-3.6$ & $5.15-5.85$ & 2 \\
\hline [13] & $40 \times 34 \times 1.6$ & FR-4 & SRR and DGS & $3.4-3.69$ & $5.15-5.825$ & 2 \\
\hline [22] & $50 \times 50 \times 1.575$ & Taconic & $\begin{array}{l}\text { Dual SRR loaded monopole } \\
\text { antenna }\end{array}$ & …......... & . & 2 \\
\hline [23] & $33 \times 32 \times 1.5$ & FR-4 & $\begin{array}{l}\text { Printing meandered slot in the } \\
\text { radiator patch and U-slot } \\
\text { in the feed line }\end{array}$ & $3.3-3.8$ & $5.2-5.7$ & 2 \\
\hline [24] & $31 \times 27 \times 1.6$ & FR-4 & Koch fractal and C-slots & $3.4-3.7$ & $5.15-5.825$ & 2 \\
\hline Proposed & $22 \times 20 \times 1.6$ & FR-4 & $\begin{array}{l}\text { Two H-shaped slots on the } \\
\text { antenna's radiating patch }\end{array}$ & $3.1-3.9$ & $5.1-5.9$ & 2 \\
\hline
\end{tabular}

WLAN notch range and the number of bands. As can be seen in Table 1, the designed antenna has the minimum size and the simplest topology compared to the ones studied in the literature.

\subsection{VSWR and Gain}

Figure 6 displays the simulated gain and voltage standing wave ratio (VSWR) of the designed antenna within the frequency range from $1 \mathrm{GHz}$ to $12 \mathrm{GHz}$.

An impedance bandwidth with suitable matching for VSWR $\leq 2$ from $2.4 \mathrm{GHz}$ to $9.6 \mathrm{GHz}$ and dual rejected bands for WLAN and WiMAX bands is observed in the UWB range with the highest gain of $1.18 \mathrm{~dB}$, excluding the rejected frequency bands.

\subsection{Radiation patterns and current distribution}

Figure 7 shows the simulation of radiation patterns at 3.4, 5.6, 6, 8.6, and $9 \mathrm{GHz}$ with H-plane and E-plane. For a

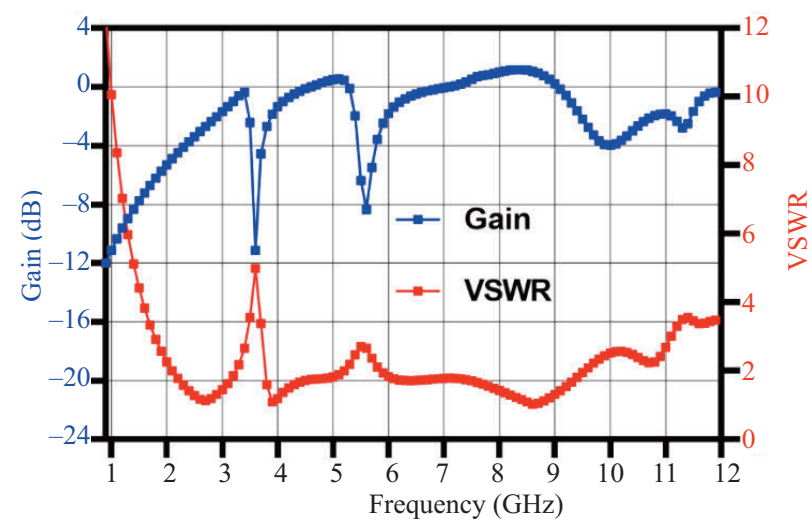

Fig. 6. Simulated VSWR and gain of the proposed antenna with two rejected bands. monopole patch antenna, the radiation patterns in the E- and H-planes are bi-directional and omnidirectional. It is comprehended that the radiation pattern in the H-plane is almost omnidirectional for the five frequencies as required for UWB bands.

To further understand the behaviour of $\mathrm{H}$-shaped slots in the lower and upper frequencies, the current distribution of the designed monopole antenna at $3.4,5.6,6,8.6 \mathrm{GHz}$ is given in Fig. 8. As depicted in Fig. 8, weighty currents are discernible along the slot edges. The highest surface

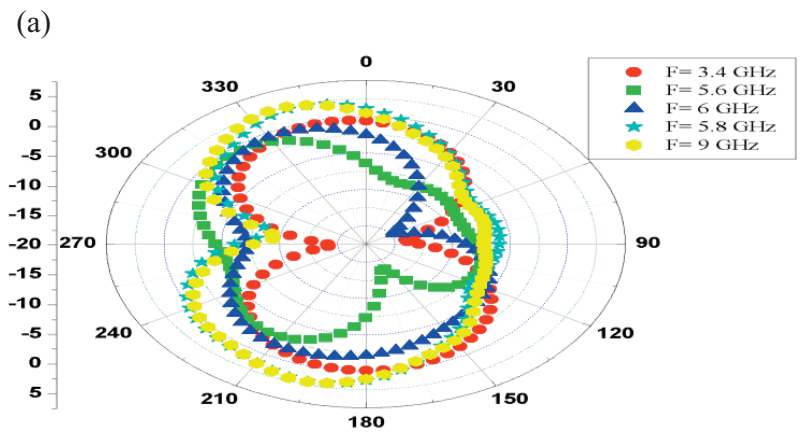

(b)

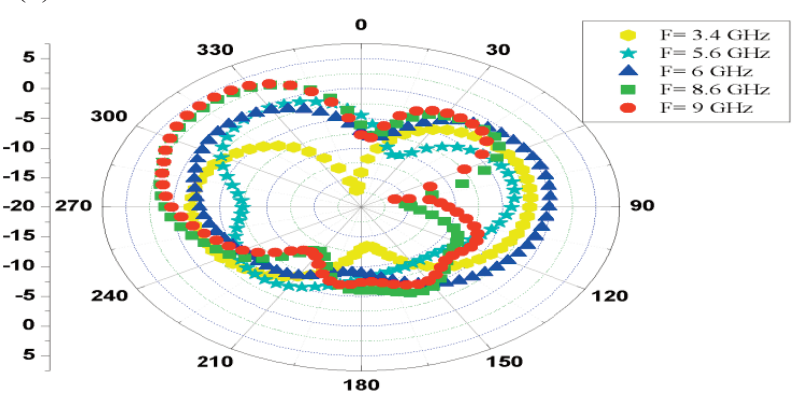

Fig. 7. Simulated radiation pattern of the proposed antenna: (a) H-plane at 3.4 , 5.6, 6, 8.6, and $9 \mathrm{GHz}$, (b) E-plane at 3.4, 5.6, 6, 8.6 , and $9 \mathrm{GHz}$. 
(a)

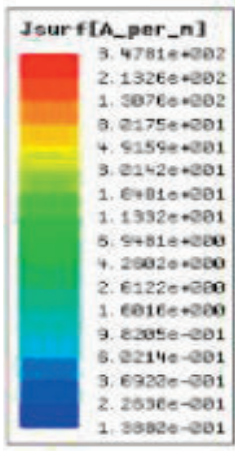

(c)

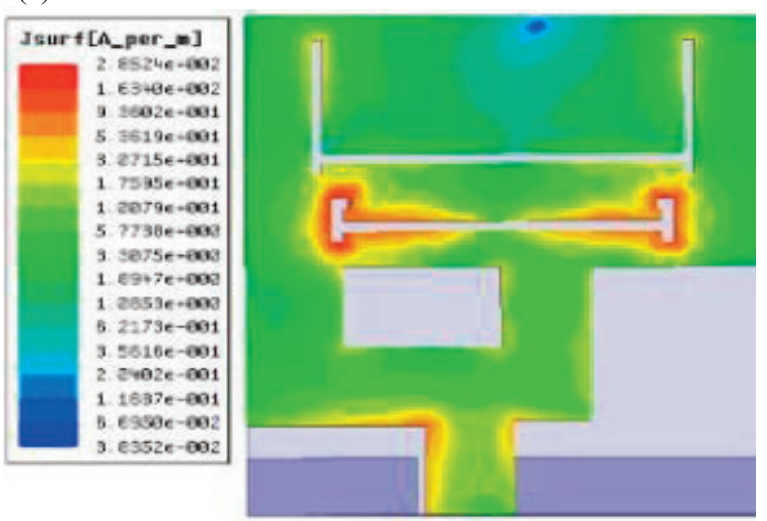

(b)
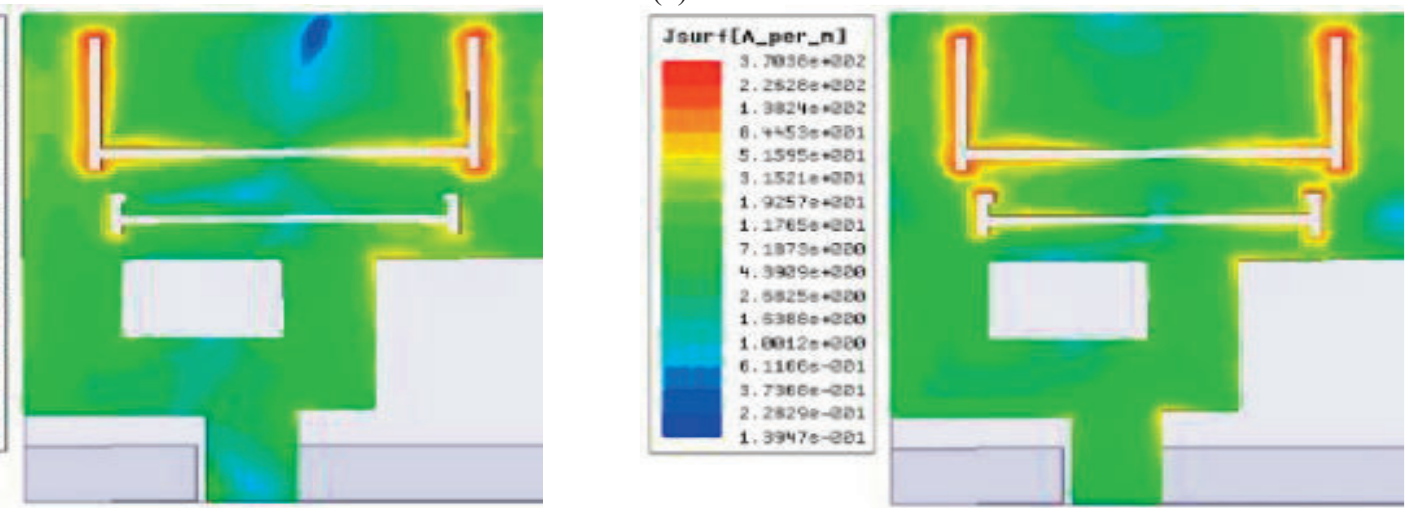

(d)

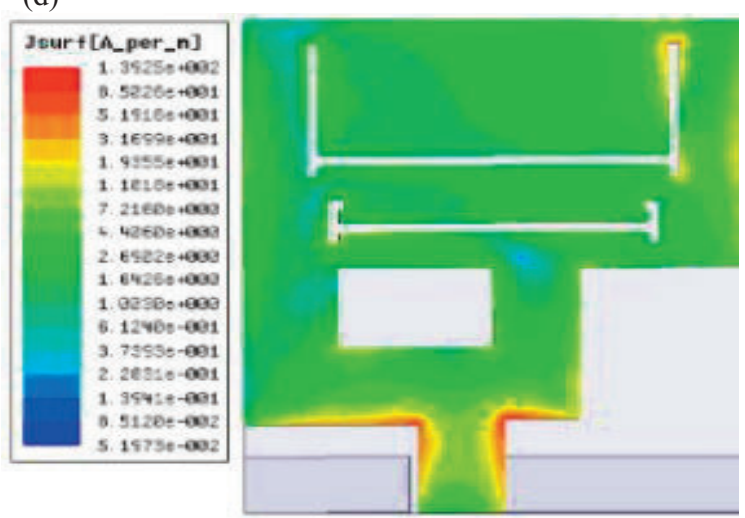

Fig. 8. Surface current distribution of (a) $3.4 \mathrm{GHz}$, (b) $5.6 \mathrm{GHz}$, (c) $6 \mathrm{GHz}$, (d) $8.6 \mathrm{GHz}$.

current is noted at the edge of the upper slot at $3.4 \mathrm{GHz}$ (Fig. 8a), while it is noticed at the edge of the lower slot at $6 \mathrm{GHz}$ (Fig. 8c). These behaviours indicate that the effective current path length is extended through the etched slots contributing to the observed dual-band rejection.

(a)

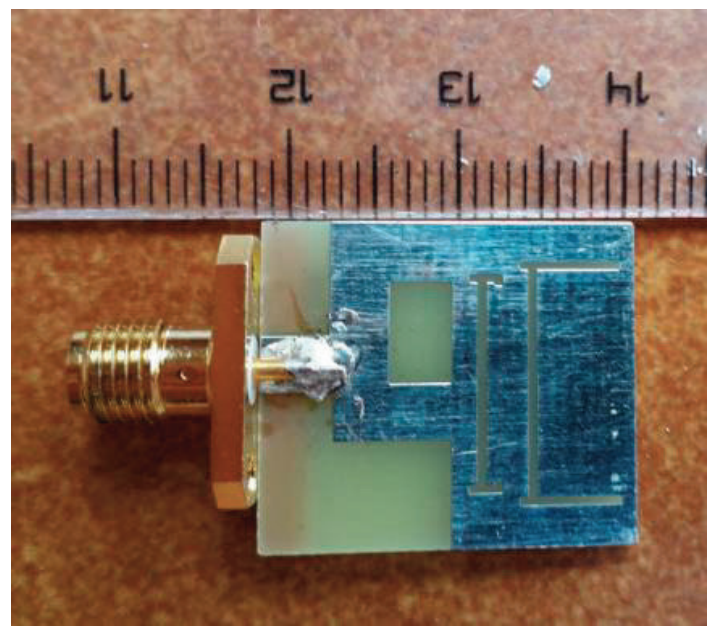

\subsection{Measurement}

The designed UWB monopole antenna prototype based on the adjusted dimensions was manufactured as depicted in Fig. 9. The $50 \Omega$ SMA connector was used to feed the

(b)

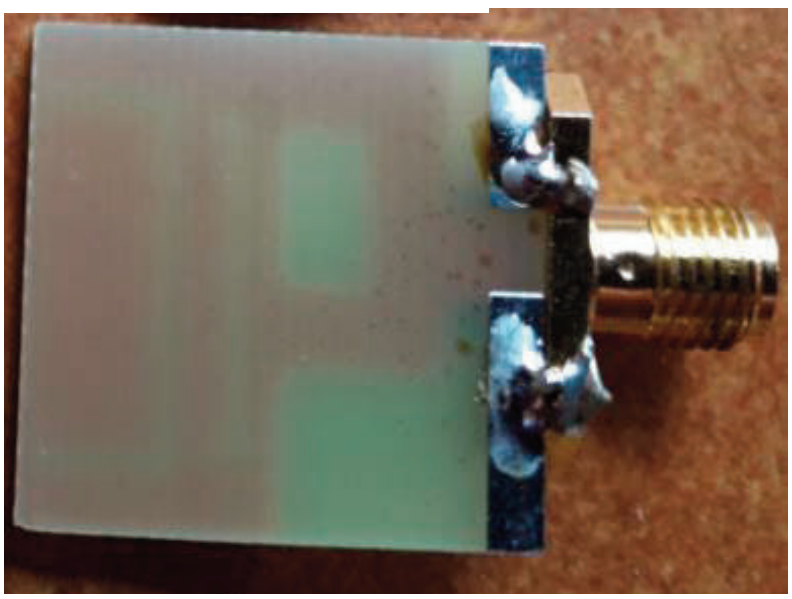

Fig. 9. The fabricated antenna prototype: (a) front view and (b) back view. 


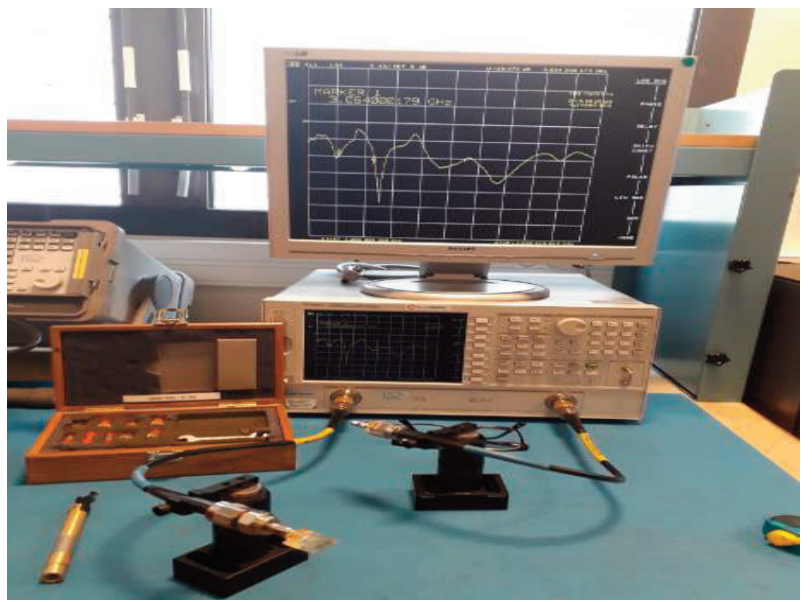

Fig. 10. The measurement setup using VNA.

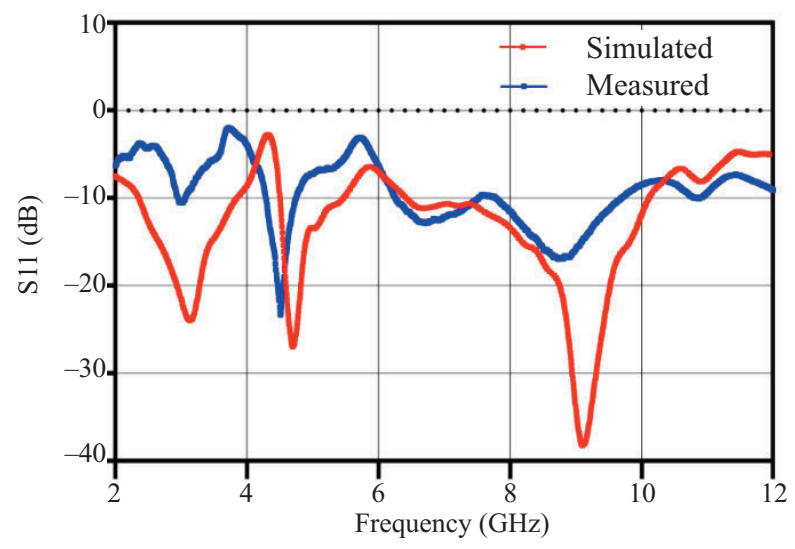

Fig. 11. The S11 measurement and simulation for the designed antenna.

antenna, and the S11 parameter was measured by using an Anritsu 37369A Vector Network Analyzer (VNA), as illustrated in Fig. 10. Figure 11 shows that the measured result agrees well with the simulated ones. The differences are predominantly caused by minor size shifts in the fabrication process, soldering between the SMA connector and the printed circuit board, and FR4 material losses.

\section{CONCLUSIONS}

A new compact UWB monopole antenna has been simulated and tested. Two H-shaped slots were printed on the patch radiator to provide two notched bands for WiMAX and WLAN systems. The antenna has a frequency band from $2.4 \mathrm{GHz}$ to more than $9.6 \mathrm{GHz}$, with notch bands from about $3.1 \mathrm{GHz}$ to $3.9 \mathrm{GHz}$ and from $5.1 \mathrm{GHz}$ to $5.9 \mathrm{GHz}$. The size of the antenna is $20 \mathrm{~mm}^{3} \times 22 \mathrm{~mm}^{3} \times$ $1.6 \mathrm{~mm}^{3}$ with tolerable input reflection and gain responses. Also, it has nearly omnidirectional radiation patterns throughout the UWB response, which makes the designed antenna valid for the wireless applications, especially for transmitting digital data directly, without using modulation techniques in a short-distance configuration.

\section{ACKNOWLEDGEMENTS}

The authors express their gratitude to the University of Mosul, Al-Esraa University College, and Mustansiriyah University in Iraq for supporting this study. The publication costs of this article were partially covered by the Estonian Academy of Sciences.

\section{REFERENCES}

1. Yassen, M. T., Hussan, M. R., Hammas, H. A., Salim, A. J. and Ali, J. K. Design of compact dual-band fractal monopole antenna with virtually extended ground plane. $A d v$. Electromagn., 2018, 7(4), 19-26.

2. Ojaroudi, M., Ghanbari, G., Ojaroudi, N. and Ghobadi, C. Small square monopole antenna for UWB applications with variable frequency band-notch function. IEEE Antennas Wirel. Propag. Lett., 2009, 8, 1061-1064.

3. Abayaje, F. and Febvre, P. A small size monopole UWB antenna used for short distance wireless baseband transmission at high data rate. In International Workshop on Antenna Technology: Small Antennas, Innovative Structures, and Applications (iWAT), Athens, Greece, March 1-3, 2017. IEEE, 2017, 296-299.

4. Shaker, A., Zainud-Deen, S. H., Mahmoud, K. R. and Ibrahem, S. M. Compact Bluetooth/UWB antenna with multi-band notched characteristics. J. Electromagn. Anal. Appl., 2011, 3(12), 512-518.

5. Hammache, B., Messai, A., Messaoudene, I. and Denidni, T. A. A compact ultra-wideband antenna with three C-shaped slots for notched band characteristics. Microw. Opt. Technol. Lett., 2019, 61(1), 275-279.

6. Ali, T., Aw, M. S. and Biradar, R. C. A A compact bandwidth enhanced antenna loaded with SRR for WLAN/WiMAX/ Satellite applications. Adv. Electromagn., 2018, 7(4), 78-84.

7. Ojaroudi, M., Ghobadi, C. and Nourinia, J. Small square monopole antenna with inverted T-shaped notch in the ground plane for UWB application. IEEE Antennas Wirel. Propag. Lett., 2009, 8, 728-731.

8. Debab, M. and Mahdjoub, Z. Characteristics UWB Planar Antenna with dual notched bands for WIMAX and WLAN. Adv. Electromagn., 2018, 7(5), 20-25.

9. Abdollahvand, M., Dadashzadeh, G. and Mostafa, D. Compact dual band-notched printed monopole antenna for UWB application. IEEE Antennas Wirel. Propag. Lett., 2010, 9, 1148-1151.

10. Gargade, P. and Gahankari, S. Dual-band-notched UWB printed monopole antenna. International Journal of Research Publications in Engineering and Technology, 2017, 3(3), 34-37.

11. Fei, P., Jiao, Y. C., Hu, W. and Zhang, F. S. A miniaturized antipodal Vivaldi antenna with improved radiation characteristics. IEEE Antennas Wirel. Propag. Lett., 2011, 10, 127-130. 
12. Li, T., Zhai, H. Q., Li, G. H. and Liang, C. H. Design of compact UWB band-notched antenna by means of electromagnetic-bandgap structures. Electron. Lett., 2012, 48(11), 608-609.

13. Sharma, M. M., Kumar, A., Yadav, S. and Ranga, Y. An ultra-wideband printed monopole antenna with dual bandnotched characteristics using DGS and SRR. Procedia Technol., 2012, 6, 778-783.

14. Kumar, M. and Nath, V. Introducing multiband and wideband microstrip patch antennas using fractal geometries: Development in last decade. Wirel. Pers. Commun., 2018, 98(2), 2079-2105.

15. Azari, A., Ismail, A., Sali, A. and Hashim, F. A new super wideband fractal monopole-dielectric resonator antenna IEEE Antennas Wirel. Propag. Lett., 2013, 12, 1014 1016.

16. Ali, J. K., Yassen, M. T., Hussan, M. R. and Salim, A. J. A printed fractal based slot antenna for multi-band wireless communication applications. In Proceedings of Progress in Electromagnetics Research Symposium, Moscow, Russia, August 19-23, 2012.

17. Ali, J. K. A new microstrip-fed printed slot antenna based on Moore space-filling geometry. In Loughborough Antennas \& Propagation Conference. IEEE, 2009, 449-452.
18. Ghatak, R., Biswas, B., Karmakar, A. and Poddar, D. R. A circular fractal UWB antenna based on Descartes circle theorem with band rejection capability. Prog. Electromagn. Res. C, 2013, 37, 235-248.

19. Tripathi, S., Mohan, A. and Yadav, S. A compact Koch fractal UWB MIMO antenna with WLAN bandrejection. IEEE Antennas Wirel. Propag. Lett., 2015, 14, $1565-1568$.

20. Hu, Z., Hu, Y., Luo, Y. and Xin, W. A novel rectangle tree fractal UWB antenna with dual-band notch characteristics. Prog. Electromagn. Res., 2016, 68, 21-30.

21. Balanis, C. A. Antenna Theory: Analysis and Design. John Wiley \& Sons, Hoboken, NJ, 2016.

22. Siddiqui, J. Y., Saha, C. and Antar, Y. M. M. Compact dualSRR-loaded UWB monopole antenna with dual frequency and wideband notch characteristics. IEEE Antennas Wirel. Propag. Lett., 2015, 14, 100-103.

23. Sohail, A., Alimgeer, K. S., Iftikhar, A., Ijaz, B., Kim, K. W. and Mohyuddin, W. Dual notch band UWB antenna with improved notch characteristics. Microw. Opt. Technol. Lett., 2018, 60(4), 925-930.

24. Tripathi, S., Yadav, S. and Mohan, A. Fractal UWB antenna with dual 3.5/5.5 GHz notched band. IEEE Indian Antenna Week, 2014.

\title{
Ultra-lairibaline (UWB) topelt H-kujulise piluga ja kahe tõkkesagedusega planaarantenn WLAN ning WiMAX rakendusteks
}

\author{
Furat Abayaje, Yaqeen Sabah Mezaal ja Ban M. Alameri
}

UWB tehnoloogial baseeruv raadioside on loodud andmete ülikiireks edastamiseks lühikeste vahemaade taha madalal saatevõimsusel. Käesolevas artiklis antakse ülevaade ülimalt miniaturiseeritud kahe tõkkesagedusega planaarantennist, mis on ette nähtud traadita kohtvõrgu WLAN ja WiMAX sidelahenduste tarvis. Laiaribalise antenni üldisi gabariite on vähendatud suuruseni $22 \times 20 \mathrm{~mm}^{2}$, parandades seeläbi side kvaliteeti UWB sides kasutatavas sagedusalas $2,4 \mathrm{GHz}-$ 9,6 GHz. Kahe H-kujulise pilu süvistamisega aktiivelemendile on saavutatud WiMAX sides kasutatavate raadiosageduste tõkestamine sagedusvahemikus $3,1 \mathrm{GHz}-3,9 \mathrm{GHz}$ ja WLAN raadiosageduste tõkestamine sagedusvahemikus 5,1 GHz $5,9 \mathrm{GHz}$. H-kujuline pilu on süvistatud mõlemasse aktiivelementi. Antenn on valmistatud FR4 trükkplaadile ja seda toidetakse koplanaarse lainejuhi (CPW) kaudu. Antenni impedantsi sobitamiseks (50 $\Omega$ ) kasutatakse koaksiaalkaablil põhinevat lahendust. Antennil on H-tasandil ringikujuline ja E-tasandil kahesuunaline suunadiagramm. Töö käigus valmistati antenni prototüüp, mida seejärel testiti ja kasutati verifitseerimiseks. 